Me refiero a una fría pared de piedra, la pared de un soneto medieval, el corazón de piedra de una mujer, la piedra atravesada en la garganta de su amante poeta.

\title{
ESTATUAS EN EL PARQUE
}

Hoy pensé en ti

cuando me detuve frente a una estatua ecuestre en medio de una plaza pública,

en ti que me habías enseñado el código de tan nobles poses.

Un caballo parado en dos patas, me dijiste, significa que el jinete murió en batalla.

Si una pata está alzada, el hombre sucumbió a las heridas en otra parte;

y si las cuatro patas tocan el piso, como en este casocascos de bronce en una base de piedraquiere decir que el hombre del caballo,

este con la atenta mirada fija en el cine cerrado de la acera de enfrente, murió de otra cosa que no fue la guerra

A la sombra de la estatua, me pregunté por los otros que simplemente caminaron por la vida sin caballo, montadura, o espada-

peatones que no podían más que poner un pie frente al otro. 
Me figuré las estatuas de los enfermos recostados en sus camas de piedra, los suicidas tanteando el filo de mármol, estatuas de víctimas de accidentes cubriéndose los ojos los asesinados cubriéndose las heridas, los ahogados jalando aire silenciosamente.

Y ahí estaba yo, subido en un bloque de granito gris-rosado cerca de los árboles dando sombra en un parque, mi nombre y fechas grabados en una placa,

arrodillado, ojos levantados, rezándole a las nubes pasajeras, siempre rogando por un día más.

\section{ViAJAR SOLO}

En la cafetería del hotel esa mañana, la mesera llevaba un uniforme rosa con "Florence" bordado sobre su corazón.

Y el hombre que checó mi maleta tenía una placa que decía "Ben". Detrás de él había una larga fila de palmeras.

En el avión, dos mujeres servían tragos de un carrito que empujaban por el angosto pasillo"Debbie" y "Lynn" de acuerdo con sus etiquetas aladas.

Y esa era mi compañía mientras volaba de costa a costa, diciendo lo preciso y solo para hablar

del café, la maleta, las botellitas de vodka.

Dije poco más que un "gracias"

y un "¿puede retirar esto, por favor?" 